\title{
Respons Optik Nanopartikel Logam Berlapis Majemuk
}

Fitriyadia*, Yudha Armana, Azrul Azwara

aProdi Fisika, FMIPA Universitas Tanjungpura

*Email : fitriyadi567@gmail.com

\begin{abstract}
Abstrak
Telah dilakukan simulasi mengenai respons optik nanopartikel logam berlapis majemuk berdasarkan aproksimasi quasi-statik elektrodinamika klasik. Penentuan nilai permitivitas logam menggunakan pemodelan Drude. Spektrum penampang lintang serapan cahaya yang ditinjau meliputi nanopartikel dengan konfigurasi metal (M), dielektrik-metal (DM), metal-dielektrik-metal (MDM), dan dielektrik-metaldielektrik-metal (DMDM). Jumlah puncak sprektrum penampang lintang serapan cahaya dipengaruhi oleh jumlah permukaan metal dan dielektrik yang bersentuhan. Hal ini sesuai dengan teori hibridisasi plasmon. Ketebalan metal juga sangat mempengaruhi spektrum penampang lintang serapan yang dihasilkan. Spektrum tersebut akan bergeser ke arah gelombang cahaya berfrekuensi rendah atau tinggi. Arah pergeseran akan berbeda-beda tergantung konfigurasi dari nanopartikel.
\end{abstract}

Kata Kunci : Model Drude, Nanopartikel, Penampang Lintang Serapan Cahaya

\section{Latar Belakang}

Jauh sebelum sains dan teknologi nano berkembang, nanopartikel khususnya yang terbuat dari logam mulia seperti emas dan perak telah banyak digunakan untuk menghasilkan produk-produk berkualitas tinggi. Salah satu contohnya adalah gelas Lycurgus yang merupakan peninggalan kerajaan Romawi pada abad ke-4 Masehi. Gelas ini dapat berubah warna sesuai dengan arah pencahayaan yang diberikan. Jika gelas disinari dari luar, gelas akan tampak berwarna hijau karena nanopartikel perak merefleksikan cahaya hijau, sedangkan jika disinari dari dalam, gelas tersebut akan berubah warna menjadi merah akibat dari transmisi cahaya merah oleh nanopartikel emas [1]. Sifat istimewa dari Lycurgus dapat terjadi karena nanopartikel emas dan perak ditanamkan dalam kaca gelas tersebut. Keberadaan nanopartikel emas dan perak inilah yang menyebabkan gelas Lycurgus menunjukkan sifat optik yang unik. Fenomena optis unik lain dari nanopartikel adalah adanya osilasi Rabi. Osilasi Rabi dapat dimodifikasi pada nanohybrid [2].

Saat ini, teknologi nanopartikel sudah mengalami kemajuan dengan sangat pesat. Berbagai jenis nanopartikel telah berhasil disintesis dan difabrikasi untuk bermacammacam aplikasi seperti terapi fototermal [3], biosensor [4], detektor ion metal berbahaya [5], antibodi [6] maupun pencitraan fotoakustik [7]. Salah satu jenis nanopartikel yang telah sukses difabrikasi dan memiliki potensi aplikasi adalah nanopartikel berlapis majemuk yang dapat digunakan untuk terapi cancer-targeting [8]. Secara spesifik, sifat optik dari nanopartikel berlapis majemuk dapat dikendalikan dengan mengatur geometri dan konfigurasi lapisan. Perbedaan geometri dan konfigurasi tersebut dapat mempengaruhi jumlah hamburan maupun serapan cahaya oleh nanopartikel. Karena itu, dalam skripsi ini, akan dimodelkan respons optik nanopartikel logam berlapis majemuk dengan metode aproksimasi kuasi-statik.

\section{Metodologi}

\subsection{Model Nanopartikel Berlapis Majemuk}

Nanopartikel berlapis $\mathrm{N}$ dengan jari-jari lapisan R1, R2, ..., dst dapat dimodelkan sebagai susunan bola konsentris seperti ditunjukkan dalam Gambar 1.

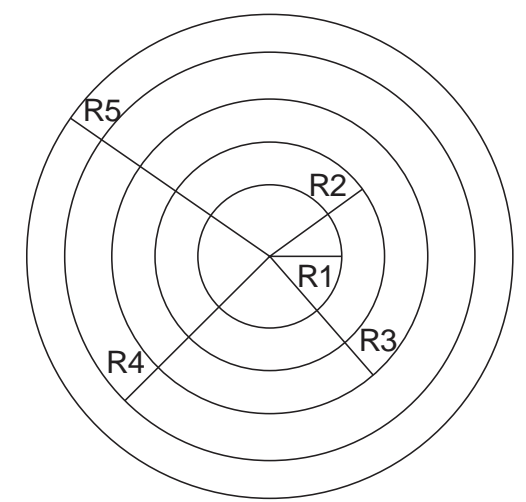

Gambar 1. Model nanopartikel berlapis majemuk.

Solusi persamaan Laplace untuk sistem ini menghasilkan ungkapan polarisabilitas dalam bentuk rumus rekursif berikut

$$
\alpha(\omega)=4 \pi \varepsilon_{0} \frac{B_{N+1}}{E_{0}},
$$

dengan

$B_{N+1}=\gamma_{N+1} A_{N+1} R_{N}^{3}$

$\gamma_{N}=\frac{\left(1+\gamma_{N-1} f_{N}\right) \varepsilon_{N}+\left(2 \gamma_{N-1} f_{N}-1\right) \varepsilon_{N-1}}{\left(1+\gamma_{N-1} f_{N}\right) 2 \varepsilon_{N}-\left(2 \gamma_{N-1} f_{N}-1\right) \varepsilon_{N-1}}$ 
serta

$$
f_{N}=\left(\frac{R_{N-2}}{R_{N-1}}\right)^{3} .
$$

Koefisien $A$ dan $B$ merupakan koefisien sembarang yang sebelumnya ditentukan dengan menyelesaikan syarat batas. Polarisabilitas pada persamaan (1) adalah fungsi dari frekuensi gelombang $(\omega)$ yang bergantung pada medan luar yang diberikan $\left(E_{0}\right)$ serta nilai permitivitas ruang hampa $\left(\varepsilon_{0}\right)$. Sedangkan koefisien $\gamma$ menunjukkan hubungan antara perbandingan antar jari-jari $(f)$ dan nilai permitivitas bahan $(\varepsilon)$.

\subsection{Tahapan Penelitian}

Penelitian ini dilakukan dengan tahapan yang ditunjukkan pada Gambar 2 .

Pembuatan program komputer untuk menghitung polarisabilitas dengan menggunakan persamaan

(1) dan cross section serapan

dengan fungsi dielektrik emas yang diberikan oleh model Drude

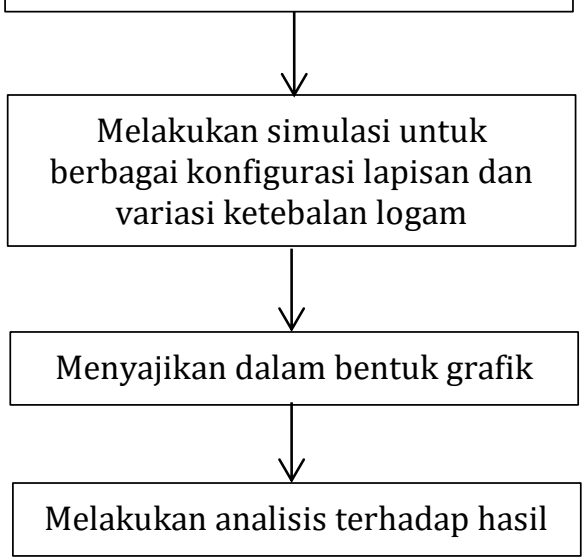

Gambar 2. Diagram alir penelitian.

\subsection{Waktu dan Tempat Penelitian}

Penelitian ini dimulai pada bulan Januari hingga Desember 2019. Penelitian ini dilakukan di Laboratorium Simulasi dan Pemodelan Jurusan Fisika FMIPA Universitas Tanjungpura.

\section{Hasil dan Pembahasan}

\subsection{Spektrum Serapan Cahaya oleh Nanopartikel Logam}

Sebuah nanopartikel logam (solid metal) yang memiliki jari-jari $\mathrm{R}$ menghasilkan daerah puncak penampang lintang serapan cahaya pada frekensi yang sama namun dengan nilai puncak penampang lintang serapan yang berbeda.

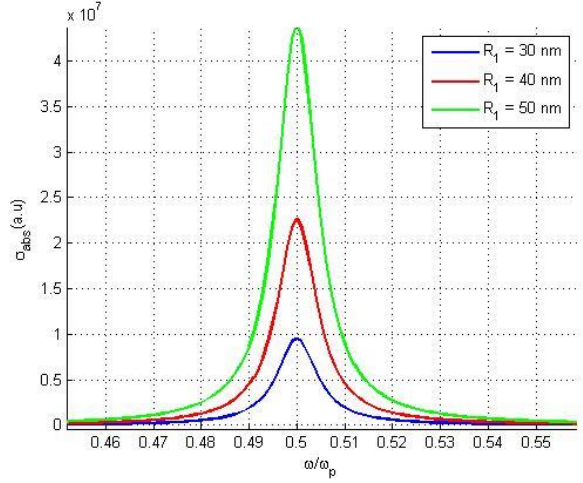

Gambar 3. Spektrum nanopartikel logam dengan variasi jari-jari logam.

Hasil perhitungan spektrum penampang lintang serapan cahaya dengan menggunakan persamaan (1) mengindikasikan adanya gejala resonansi yang terjadi pada frekuensi $\omega=0,5 \omega_{p}$ yang tidak dipengaruhi oleh nilai jari-jari nanopartikel, sebagaimana ditunjukkan dalam Gambar 3. Peningkatan jari-jari nanopartikel hanya berdampak pada peningkatan nilai puncak penampang lintang serapan cahaya. Secara teoritis, nilai $\omega=0,5 \omega_{p}$ ini merupakan konsekuensi dari syarat Fröhlich $\operatorname{Re}[\varepsilon(\omega)]=$ $-2 \varepsilon_{\text {ling. }}$. Substitusi model Drude untuk nilai $\gamma=0$ ke dalam syarat Fröhlich serta dengan menggunakan $\varepsilon_{\text {ling }}=1,5$ dapat menunjukkan bahwa frekuensi resonansi ini bernilai $\omega=0,5 \omega_{p}$.

\subsection{Spektrum Serapan Cahaya oleh Nanopartikel \\ Dielektrik-Metal (DM)}

Nanopartikel logam dengan inti berbahan dielektrik berkonstanta $\varepsilon_{d}=1,5 \quad$ yang ditempatkan pada suatu medium dengan fungsi dielektrik sama dengan inti akan menghasilkan respons optik seperti ditampilkan pada Gambar 4.

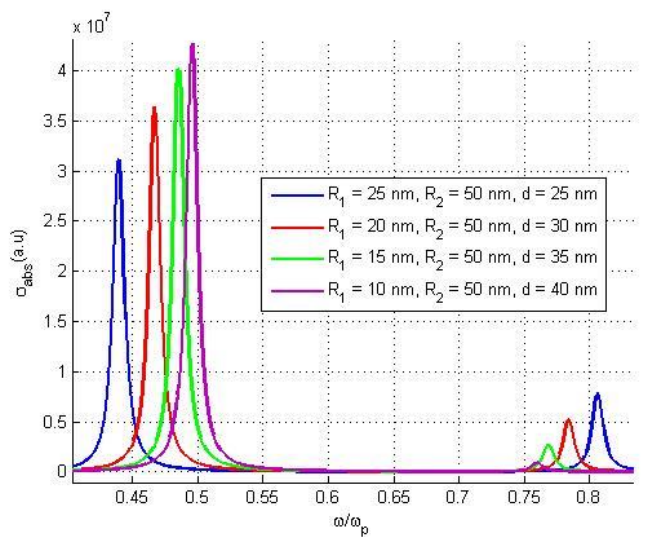

Gambar 4. Spektrum penampang lintang serapan cahaya pada nanopartikel DM dengan variasi ketebalan metal. 
Berdasarkan Gambar 4, terlihat bahwa ketebalan logam mempengaruhi spektrum serapan cahaya oleh nanopartikel DM. Ketebalan logam diatur dengan memvariasikan jari-jari inti. Semakin kecil jari-jari inti, maka akan semakin tebal logam yang digunakan selama ukuran naopartikel tetap sama.

Pertambahan ketebalan metal mengakibatkan adanya pergeseran daerah serapan ke frekuensi yang lebih tinggi dan menyerap cahaya lebih banyak untuk daerah pada rentang frekuensi $0,4 \omega_{p}$ sampai $0,55 \omega_{p}$. Berbeda dengan daerah frekuensi rendah, pada daerah dengan frekuensi yang lebih tinggi yaitu pada frekuensi di atas $0,75 \omega_{p}$ terjadi penurunan puncak penampang lintang serapan cahaya dan pergeseran ke daerah frekuensi yang lebih rendah. Nanopartikel dengan logam yang memiliki ketebalan $25 \mathrm{~nm}$ memiliki jarak antar puncak penampang lintang serapan lebih jauh dibandingkan dengan nanopartikel yang memiliki ketebalan logam $40 \mathrm{~nm}$. Hal ini menunjukkan bahwa ketebalan logam juga mempengaruhi jarak puncak penampang lintang serapan cahaya oleh nanopartikel. Seiring dengan pengurangan jari-jari inti nanopartikel tersebut, puncak penampang lintang pada frekuensi tinggi menurun dan akhirnya akan menghilang. Hilangnya daerah serapan pada frekuensi tinggi berdampak pada serapan di frekuensi rendah mendekati nilai $0,5 \omega_{p}$ yang sesuai dengan daerah serapan untuk nanopartikel logam tanpa lapisan tambahan.

\subsection{Spektrum Serapan Cahaya oleh Nanopartikel Berstruktur Metal- Dielektrik-Metal (MDM)}

Nanopartikel logam dengan struktur MDM menghasilkan tiga daerah puncak serapan yang berbeda. Gambar 5 memperlihatkan perbedaan spektrum serapan pada masing-masing daerah frekuensi penampang lintang serapan.

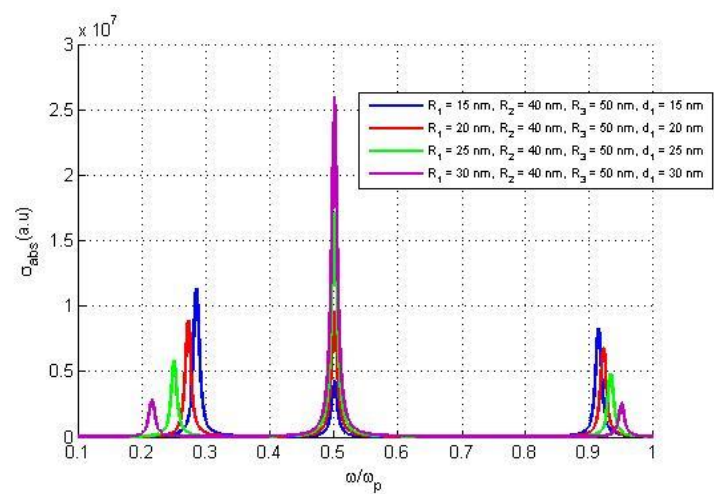

Gambar 5. Spektrum penampang lintang serapan cahaya pada nanopartikel MDM dengan variasi ketebalan inti.
Spektrum penampang lintang serapan di daerah frekuensi rendah mengalami pergeseran ke frekuensi yang lebih rendah serta terjadi penurunan puncak penampang lintang serapan ketika ketebalan inti nanopartikel bertambah. Sedangkan spektrum pada frekuensi sedang tidak mengalami pergeseran tetapi mengalami peningkatan nilai penampang lintang serapan cahaya. Spektrum di frekuensi tinggi memiliki spektrum yang berkebalikan arah dengan spektrum di frekuensi rendah. Pada frekuensi tinggi, peningkatan ketebalan akan mengakibatkan spektrum bergeser ke frekuensi yang lebih tinggi tetapi tetap mengalami penurunan nilai puncak penampang lintang serapan cahaya.

\subsection{Spektrum Serapan Cahaya oleh Nanopartikel Berstruktur Dielektrik-Metal-Dielektrik-Metal (DMDM)}

Gambar 6 menunjukkan adanya empat daerah frekuensi serapan pada nanopartikel logam dengan struktur DMDM. Daerah frekuensi paling rendah berada pada rentang $0,2 \omega_{p}$ sampai dengan $0,3 \omega_{p}$. Daerah ke-2 berada pada frekuensi antara $0,4 \omega_{p}$ sampai $0,5 \omega_{p}$ dan daerah ke-3 direntang frekuensi $0,75 \omega_{p}$ hingga $0,8 \omega_{p}$. Sedangkan daerah serapan pada frekuensi tinggi berada di atas frekuensi $0,9 \omega_{p}$.

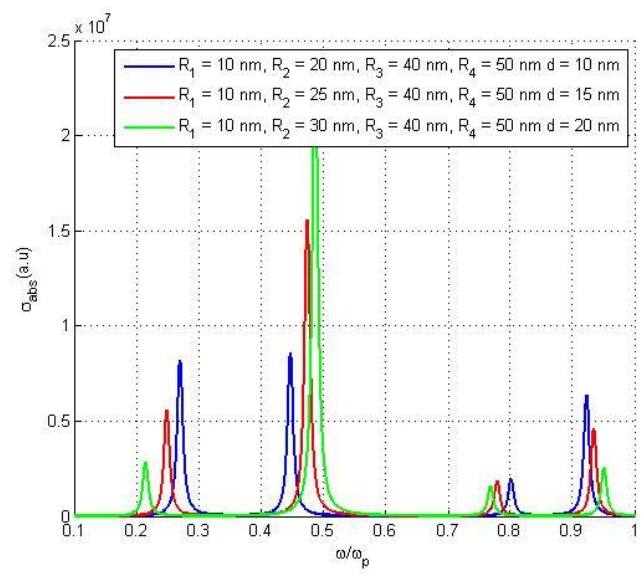

Gambar 6. Spektrum penampang lintang serapan cahaya pada nanopartikel DMDM dengan variasi ketebalan logam lapisan ke-2.

Tiap daerah serapan cahaya memiliki pola spektrum yang berbeda-beda ketika ketebalan lapisan logam ke-2 ditingkatkan. Daerah frekuensi paling rendah dan paling tinggi mengalami penurunan tingkat penampang lintang serapan ketika terjadi penambahan ketebalan dari lapisan logam yang divariasikan. Namun pada frekuensi rendah, spektrum 
penampang lintang serapan cahaya bergeser ke daerah dengan frekuensi yang lebih rendah (red shift) dan berbanding terbalik dengan daerah serapan pada frekuensi tinggi yang bergeser ke frekuensi yang lebih tinggi (blue shift). Pergeseran yang serupa terjadi di daerah dengan frekuensi $0,75 \omega_{p}$ hingga $0,8 \omega_{p}$ yang mengalami penurunan puncak daerah serapan dan pergeseran ke frekuensi yang lebih rendah.

Berbeda dengan ketiga daerah serapan sebelumnya, pada daerah dengan rentang frekuensi antara $0,4 \omega_{p}$ sampai $0,5 \omega_{p}$ terjadi peningkatan puncak penampang lintang serapan cahaya yang meningkat seiring dengan penambahan ketebalan logam pada lapisan ke-2 dan mengakibatkan pergeseran ke frekuensi yang lebih tinggi.

\section{Kesimpulan}

Berdasarkan hasil simulasi yang telah dilakukan, diketahui bahwa ketebalan dari lapisan logam pada nanopartikel logam berlapis majemuk mempengaruhi hasil spektrum serapan cahaya yang dihasilkan. Terjadi peningkatan maupun penurunan puncak penampang lintang serapan cahaya ketika ketebalan lapisan logam bertambah dan terjadi pergeseran ke daerah frekuensi yang lebih besar atau yang lebih kecil.

\section{Daftar Pustaka}

[1] Freestone, I., Meeks, N., Sax, M. \& Higgitt, C., The Lycurgus Cup - A Roman
Nanotechnology. Gold Bulletin, 40(4), 270277, 2007.

[2] Nugroho, B. S. dan Arman, Y., Modifikasi Osilasi Rabi pada Nanoparticle Heterodimer: Pengaruh Jarak antar Partikel dan Intensitas Medan Iluminasi. POSITRON, 8(2), 7-13, 2018.

[3] Ali, M. R., Wu, Y. \& El-Sayed, M. A., Gold Nanoparticle-Assisted Plasmonic Photothermal Therapy Advances Towards Clinical Application. Journal of Physical Chemistry, 1-60, 2019.

[4] Lee, J.-H.et al., Application of Gold Nanoparticle to Plasmonic Biosensors. International Journal of Molecular Sciences, 1-14, 2018.

[5] Priyadarshini, E. \& Phardan, N., Gold nanoparticles as efficient sensors in colorimetric detection of toxic metal ions: A review. Sensors and Actuators B: Chemical, 238, 888-902, 2017.

[6] Jazayeri, M. H. et al., Various Methods of Gold NAnoparticles (GNPs) Conjugation to Antibodies. Sensing and Bio-Sensing Research, Volume 9, 17-22, 2016.

[7] Lee, J.-H.et al., Application of Gold Nanoparticle to Plasmonic Biosensors. International Journal of Molecular Sciences, 1-14, 2018.

[8] Oh, K. S. et al., The multilayer nanoparticles formed by layer by layer approach for cancer-targeting therapy. Journal of Controlled Release, 9-15, 2013. 